\title{
Reproductive biology of Sympterygia bonapartii (Chondrichthyes: Rajiformes: Arhynchobatidae) in San Matías Gulf, Patagonia, Argentina
}

\author{
María L. Estalles ${ }^{1}$, María R. Perier ${ }^{2}$ and Edgardo E. Di Giácomo ${ }^{2}$
}

This study estimates and analyses the reproductive parameters and cycle of Sympterygia bonapartii in San Matías Gulf, northern Patagonia, Argentina. A total of 827 males and 1,299 females were analysed. Males ranged from 185 to $687 \mathrm{~mm}$ of total length (TL) and females from 180 to $742 \mathrm{~mm}$ TL. Sexual dimorphism was detected; females were larger, heavier, exhibited heavier livers, wider discs and matured at lager sizes than males. Immature females ranged from 180 to $625 \mathrm{~mm}$ TL, maturing females from 408 to $720 \mathrm{~mm} \mathrm{TL}$, mature ones from 514 to $742 \mathrm{~mm}$ TL and females with egg capsules from 580 to $730 \mathrm{~mm}$ TL. Immature males ranged from 185 to $545 \mathrm{~mm}$ TL, maturing ones from 410 to $620 \mathrm{~mm}$ TL and mature males from 505 to $687 \mathrm{~mm}$ TL. Size at which $50 \%$ of the skates reached maturity was estimated to be $545 \mathrm{~mm}$ TL for males and 594 $\mathrm{mm}$ TL for females. According to the reproductive indexes analysed, S. bonapartii exhibited a seasonal reproductive pattern. Mating may occur during winter-early spring and the egg-laying season, during spring and summer.

Keywords: Elasmobranchii, Reproduction, Skate, South Western Atlantic Ocean.

El presente estudio estima y analiza los parámetros reproductivos y el ciclo reproductivo de Sympterygia bonapartii en el Golfo San Matías, Patagonia norte, Argentina. Se analizaron 827 machos y 1.299 hembras. Los machos midieron entre 185 y $687 \mathrm{~mm}$ de largo total (LT) y las hembras entre 180 y $742 \mathrm{~mm}$ LT. Se detectó dimorfismo sexual; las hembras fueron más grandes y pesadas que los machos y presentaron anchos de disco, pesos de hígado y tallas de madurez sexual mayores a los de los machos. Las hembras inmaduras midieron entre 180 y $625 \mathrm{~mm}$ LT, las hembras en maduración entre 408 y $720 \mathrm{~mm}$ LT, las maduras entre 514 y $742 \mathrm{~mm}$ LT y las hembras con cápsulas entre 580 y $730 \mathrm{~mm}$ LT. Los machos inmaduros midieron entre 185 y $545 \mathrm{~mm}$ LT, los machos en maduración entre 410 y $620 \mathrm{~mm}$ LT y los maduros entre 505 y $687 \mathrm{~mm}$ LT. La talla media de madurez sexual fue estimada en $545 \mathrm{~mm}$ LT para los machos y $594 \mathrm{~mm}$ LT para las hembras. De acuerdo con los índices reproductivos analizados, $S$. bonapartii se reproduce estacionalmente. El apareamiento ocurriría durante el invierno y la primavera y la temporada de puesta durante la primavera y el verano.

Palabras claves: Atlántico Sudoccidental, Elasmobranchii, Rayas, Reproducción.

\section{Introduction}

Skates (Chondrichthyes: Rajiformes) are the most diverse group of batoids comprising 27 genera and 245 species (Ebert, Compagno, 2007). The genus Sympterygia (Arhynchobatidae) is composed of four species endemic to South America. Sympterygia brevicaudata (Cope, 1877) and S. lima (Poeppig, 1835) are distributed in the Southeast Pacific, while $S$. bonapartii Müller \& Henle, 1841 and $S$. acuta Garman, 1877 are found in the Southwest Atlantic.

The smallnose fanskate $S$. bonapartii is distributed from Rio de Janeiro $\left(23^{\circ} \mathrm{S}\right)$, Brazil, to Santa Cruz $\left(54^{\circ} \mathrm{S}\right)$, Argentina (Figueiredo, Menezes, 1977; Menni, Stehmann, 2000). This skate is one of the most abundant and fished along the Argentine coast. It is caught and landed by bottom trawlers in mixed-species fisheries and in fisheries targeting the common hake Merluccius hubbsi Marini, 1933, where it is part of the bycatch (Massa et al., 2004; Tamini et al., 2006; Estalles et al., 2011). It is also caught and discarded in the fishery of the Patagonian red shrimp Pleoticus muelleri (Bate, 1888), where its discards are thought to represent an important fraction of its stock (Cedrola et al., 2005).

Biological information of $S$. bonapartii has been reported for some areas of its distribution. According to previous studies, it presents a seasonal reproductive cycle in the wild while it is able to reproduce throughout the year in captivity (Mabragaña et al., 2002; Jañez, Sueiro, 2009). Estimations of size at maturity also vary among studies and they were performed in the northern area of its distribution (Mabragaña et al., 2002; Oddone, Velasco, 2004; Díaz

\footnotetext{
${ }^{1}$ Instituto de Investigaciones Marinas y Costeras, Consejo Nacional de Investigaciones Científicas y Técnicas (CONICET) and Universidad Nacional de Mar del Plata, Departamento de Ciencias Marinas, Funes 3350, B7602AYL, Mar del Plata, Buenos Aires, Argentina. mariluestalles@gmail.com (corresponding author)

${ }^{2}$ Instituto de Biología Marina y Pesquera “Alte. Storni” and Universidad Nacional del Comahue, Güemes 1030, (8520), San Antonio Oeste, Río Negro, Argentina. (MRP) raquelperier@gmail.com, (EEDG) edgardodigiacomo@gmail.com
} 
Andrade, 2011; Basallo, Oddone, 2014). In Patagonia, the biological information on the species is scarce. The aim of the present study is to provide information on the reproductive parameters and reproductive cycle of $S$. bonapartii in San Matías Gulf, northern Patagonia, Argentina.

\section{Materials and methods}

San Matías Gulf (SMG; $41^{\circ}-42^{\circ} \mathrm{S} ; 64^{\circ}-65^{\circ} \mathrm{W}$; Fig. 1) is a semi-closed basin separated from the continental shelf by an $80 \mathrm{~m}$-deep sill. During spring and summer a NESW thermohaline front divides the gulf into a northern and southern water mass ( 1 to $3^{\circ} \mathrm{C} ; 2 \%$ salinity difference). During autumn and winter the front disappears and the water mass of the gulf become homogeneous (Piola, Scasso, 1988).

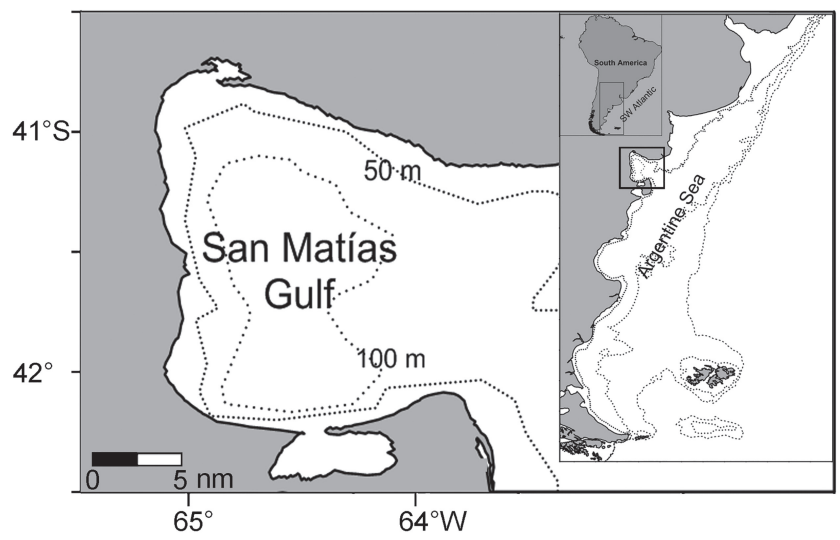

Fig. 1. Geographic location of the study area, San Matías Gulf (Argentina).

Samples of $S$. bonapartii came from three different sources: bottom trawl research surveys, the on-board observer programme (OBP) of Río Negro Province, and local fishprocessing industries. All the samples were captured by bottom trawlers. Research surveys were conducted during spring (October-December) from 2004 to 2007. Hauls were carried out covering the area of SMG at a depth-range of 40$175 \mathrm{~m}$. The OBP of Río Negro Province provided samples of juveniles of $S$. bonapartii caught by commercial vessels during 2007 and 2008. Individuals composing the commercial fraction were sampled monthly from April 2007 to April 2008, June 2008 to October 2008, and December 2008 to February 2009 at local fish-processing industries.

Skates were measured and weighted in order to assess their morphological characteristics. Total length (TL; mm) was measured from the tip of the snout to the tip of the tail and disc width (DW; mm) as the maximum distance between wing tips. Total weight (TW; g), liver weight (LW; g) and the sex of each individual were recorded. The TL-DW, TLTW and TL-LW relationships were estimated for each sex and compared between sexes with an ANCOVA (Zar, 1984). Before comparing the curves data were log-transformed. Analyses were performed using the $\mathrm{R}$ statistical software (R Core Team, 2010). Complete metrics were not obtained from every individual, and thus, every test and analysis was presented with its sample size.

The maturity condition of the individuals was assessed by the macroscopic observation of the reproductive organs. Males and females were classified into three and four reproductive stages respectively, modifying the scale of maturity stages proposed by Stehmann (2002) as follows:

Immature males: flexible claspers shorter than the pelvic fins; small testes with abundant epigonal organ and straight and thread-like sperm ducts. Maturing males: claspers larger than the pelvic fins but flexible; enlarged testes with differentiated lobules and straight sperm ducts. Mature males: claspers larger than pelvic fins and calcified; testes enlarged and coiled sperm ducts.

Immature females: small ovaries without differentiated follicles; oviducal glands undifferentiated from uteri and narrow and thread-like uteri. Maturing females: ovaries with ovarian follicles becoming differentiated but lacking yolked oocytes; narrow uteri and developing oviducal glands. Mature females: large ovaries with yolked mature oocytes of different sizes; uteri enlarged and oviducal glands fully developed. Mature females with egg capsules: presence of egg capsules beginning to be formed or fully formed in their uteri.

For males, the length of the left clasper was measured (CL; $\mathrm{mm}$ ) from the end of the cloaca to its tip and the weight of the paired testes recorded (GW;g). For females, the maximum width of the left oviducal gland was measured (OGW; mm). The number of yolked ovarian oocytes was counted and a mean value was estimated (NYO). The diameter of the largest yolked ovarian oocyte was also measured, in each ovary, and a mean value was estimated (MOD; $\mathrm{mm}$ ). The weight of the paired ovaries $(\mathrm{GW} ; \mathrm{g})$ and oviducal glands $(\mathrm{OG} ; \mathrm{g})$ were recorded. For TL-MOD and TL-NYO relationships, the correlation coefficient Pearson's $(r)$ was estimated since variables were normally distributed (Zar, 1984). Normality was tested with Kolmogorov-Smirnov $(K S)$ test (For TL $K S=0.05$, for NYO $K S=0.08$ and for MOD $K S=0.07 ; \mathrm{n}=255$; $P>0.05$; Zar, 1984).

When egg capsules were found their length and width were measured, according to Hubbs, Ishiyama (1968), and their weight recorded.

The length at which $50 \%$ of the skates reached maturity $\left(\mathrm{TL}_{50 \%}\right)$ was estimated using a logistic model for each sex. To fit the model binomial maturity data (immature 0 , mature 1 ) was determined by sex at $10 \mathrm{~mm}$ intervals (Estalles, 2012). The model used was:

$$
P=\frac{1}{1\left(1+e^{-r(T L-\mathrm{TL} 50 \%)}\right)}
$$

Where: $P$ is the proportion of mature skates at a given length-class interval, $r$ is a fitted parameter, $T L$ is the lengthclass interval for which the proportion of mature individuals is estimated, and $\mathrm{TL}_{50 \%}$ is the length-class interval at which $50 \%$ of the skates are mature. The model was fitted for each sex with FISHPARM 3.05 (Prager et al., 1989). 
Several indexes were estimated to assess the reproductive cycle of the species. Only mature individuals sampled during 2007, 2008 and 2009 were included in these analyses (Tab. 1).

Monthly variations in the gonadosomatic (GSI) and hepatosomatic (HSI) indexes were analysed in both sexes: $\mathrm{GSI}=100 \mathrm{xGWxTW}{ }^{-1}$ and HSI $=100 \mathrm{xLWxTW}^{-1}$. For females, the oviducal gland index (OGI) was also estimated: OGI $=$ $100 \mathrm{xOGxTW}{ }^{-1}$. Monthly changes in the ovarian condition were assessed by analysing the NYO and MOD (Conrath, 2005). The samples taken during September and October were analysed together, since only two NYO and MOD values were obtained during October.
The hypothesis of no interannual variation in reproductive indexes was analyzed with Mann-Whitney test for unpaired samples (Zar, 1984). The test compared the mean values of indexes between months of consecutive years for both sexes. Since in most cases no significant differences were found data was analyzed pooled (S1-3 - Available only as online supplementary files accessed with the online version of the article at http://www.scielo.br/ni).

Non-parametric analyses of variance, Kruskal-Wallis test $(H)$, were used to determine significant differences in the monthly variation of the reproductive indexes (GSI, HSI, OGI, NYO, MOD; Zar, 1984).

Tab. 1. Number of individuals sampled for estimating the reproductive indexes of Sympterygia bonapartii from San Matías Gulf (Argentina).

\begin{tabular}{|c|c|c|c|c|c|c|c|c|c|c|c|c|c|}
\hline \multicolumn{14}{|c|}{ Number of individuals sampled } \\
\hline \multirow{2}{*}{ Sex } & \multirow{2}{*}{ Year } & & \multicolumn{11}{|c|}{ Month } \\
\hline & & APR & MAY & JUN & JUL & AUG & SEP & OCT & $\mathrm{NOV}$ & DEC & JAN & FEB & MAR \\
\hline \multirow{3}{*}{ Male } & 2007 & 34 & 18 & 5 & 17 & 6 & 1 & 19 & 42 & 8 & - & - & - \\
\hline & 2008 & 1 & - & - & 13 & 1 & 8 & - & - & 6 & 3 & - & - \\
\hline & 2009 & - & - & - & - & - & - & - & - & - & 6 & 7 & - \\
\hline \multirow{3}{*}{ Female } & 2007 & 10 & 27 & 31 & 37 & 16 & 28 & 34 & 32 & 4 & - & - & - \\
\hline & 2008 & 33 & - & 17 & 10 & 12 & 6 & 2 & - & 19 & 18 & 28 & 25 \\
\hline & 2009 & - & - & - & - & - & - & - & - & - & 10 & 9 & - \\
\hline
\end{tabular}

\section{Results}

A total of 2,126 individuals (827 males and 1,299 females) were sampled. Males ranged from 185 to $687 \mathrm{~mm}$ TL and females from 180 to $742 \mathrm{~mm}$ TL (Fig. 2). Females were heavier, showed wider discs and heavier livers than males of the same length (Tab. 2).

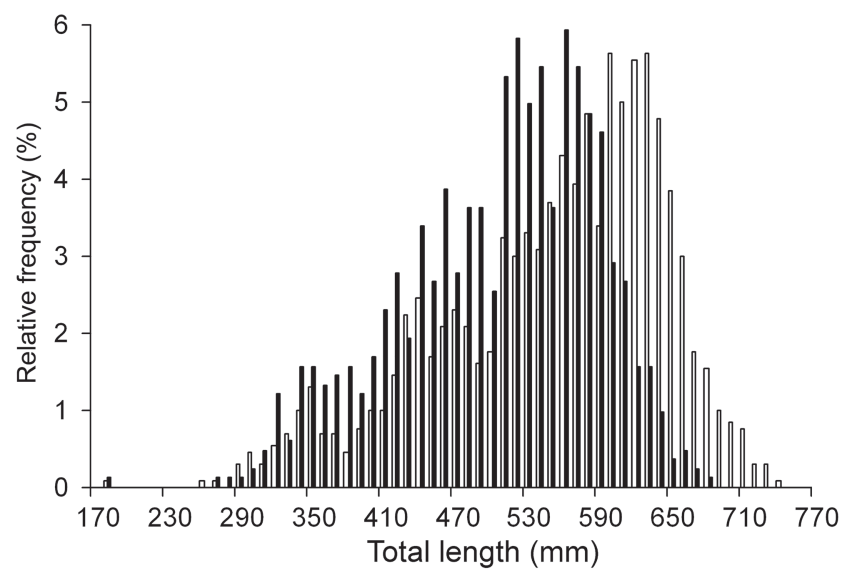

Fig. 2. Size frequency distribution of the individuals analyzed of Sympterygia bonapartii from San Matías Gulf (Argentina). Males (घ) $n=827$ and females ( $\square$ ) $n=1,299$.

The smallest mature male was $505 \mathrm{~mm} \mathrm{TL}$ and the largest maturing one $620 \mathrm{~mm}$ TL (Tab. 3). The relationship TL-CL showed a continuous increase, with a range between 490 and $620 \mathrm{~mm} \mathrm{TL}$ at which the reproductive stages overlapped (Fig. 3). Size at $50 \%$ of maturity was estimated to be $545 \mathrm{~mm}$ TL (Fig. 4).

The onset of vitellogenesis for $S$. bonapartii could be set when the diameter of the largest yolked ovarian oocyte is greater than $6.5 \mathrm{~mm}$ and the ovulation could be set when oocytes are greater than $38 \mathrm{~mm}$ (Tab. 4).

The width of the oviducal gland was an indicator of the maturity condition of the females and it showed an abrupt increase between 520 and $620 \mathrm{~mm}$ TL (Fig. 5). The smallest mature female was $514 \mathrm{~mm}$ TL and the largest maturing one $720 \mathrm{~mm}$ TL (Tab. 4). Size at $50 \%$ of maturity was estimated to be $594 \mathrm{~mm}$ TL (Fig. 4).

Females with egg capsules were recorded during spring and summer. This stage of maturity presented less ovarian oocytes than mature females but, these oocytes were of larger sizes (Tab. 4). Eight egg capsules were found completely formed. They measured $77.90 \pm 5.10 \mathrm{~mm}$ in length, $47.30 \pm 2.40 \mathrm{~mm}$ in width and their weight was $24.50 \pm 4.90 \mathrm{~g}$ (mean \pm standard deviation).

Positive correlations were detected between the TL of the female and MOD and NYO respectively $(r=0.37 ; P<$ 0.001 for MOD and $r=0.30 ; P<0.001$ for NYO; $n=255$ ).

The HSI differed significantly throughout the year $(H=46.87 ;$ d.f. $=11 ; P<0.001$ and $H=91.96 ;$ d.f. $=12 ; P<$ 0.001 for males and females respectively). For males, the HSI alternated between high and low values from April to August. After that, the HSI decreased until February (Fig. 6). For females, the HSI increased from July to September and then, it decreased until February when its lowest value was recorded (Fig. 6). 
Tab. 2. Relationships analyzed for Sympterygia bonapartii from San Matías Gulf (Argentina). Total length (TL; mm), disc width (DW; mm), total weight (TW; g); liver weight (LW; g) for males (M) and females (F); correlation coefficient $\left(\mathrm{R}^{2}\right)$ and sample number (n); F- test results.

\begin{tabular}{|c|c|c|c|c|c|c|c|}
\hline Curve & Sex & Equation & $\mathrm{R}^{2}$ & $\mathrm{n}$ & $F$ value & $d . f_{(I ; 2)}$ & $P<$ \\
\hline \multirow{2}{*}{ TW-TL } & M & $\mathrm{TW}=9 \times 10-{ }^{-6} \mathrm{TL}^{2.9577}$ & 0.97 & 580 & \multirow[t]{2}{*}{13.87} & \multirow[t]{2}{*}{$1 ; 1,612$} & \multirow[t]{2}{*}{0.001} \\
\hline & $\mathrm{F}$ & $\mathrm{TW}=4 \times 10^{-6} \mathrm{TL}^{3.1007}$ & 0.97 & 1,036 & & & \\
\hline \multirow{2}{*}{ DW-TL } & M & $\mathrm{DW}=(0.6236 \mathrm{x} T \mathrm{TL})+28.308$ & 0.97 & 264 & \multirow[t]{2}{*}{13.80} & \multirow[t]{2}{*}{$1 ; 708$} & \multirow[t]{2}{*}{0.001} \\
\hline & $\mathrm{F}$ & $\mathrm{DW}=(0.6578 \mathrm{x} \mathrm{TL}+17.473$ & 0.97 & 448 & & & \\
\hline \multirow{2}{*}{ LW-TL } & M & $\mathrm{LW}=6 \times 10^{-8} \mathrm{TL}^{3.1644}$ & 0.82 & 454 & \multirow[t]{2}{*}{55.45} & \multirow[t]{2}{*}{$1 ; 323$} & \multirow[t]{2}{*}{0.001} \\
\hline & $\mathrm{F}$ & $\mathrm{LW}=9 \times 10^{-10} \mathrm{TL}^{3.8735}$ & 0.84 & 873 & & & \\
\hline
\end{tabular}

Tab. 3. Characteristics of the maturity stages of males of Sympterygia bonapartii from San Matías Gulf (Argentina). $T L=$ total length; $C L=$ clasper length; $G W=$ weight of the paired testes.

\begin{tabular}{cccc}
\hline Males & Immature & Maturing & Mature \\
\hline$T L$ range $(\mathrm{mm})$ & $185-545$ & $410-620$ & $505-687$ \\
$C L$ range $(\mathrm{mm})$ & $15-97$ & $62-180$ & $140-240$ \\
$G W$ range $(\mathrm{g})$ & $0.18-8.38$ & $2.68-26.27$ & $3.80-64.39$ \\
mean $\pm \mathrm{SD}$ & $3.17 \pm 2.15$ & $10.77 \pm 5.73$ & $21.44 \pm 11.44$ \\
Presence & Year round & Year round & Year round \\
$\mathrm{n}(\%)$ & $286(35 \%)$ & $258(31 \%)$ & $283(34 \%)$ \\
\hline $\mathrm{NT}$ & \multicolumn{3}{c}{827}
\end{tabular}

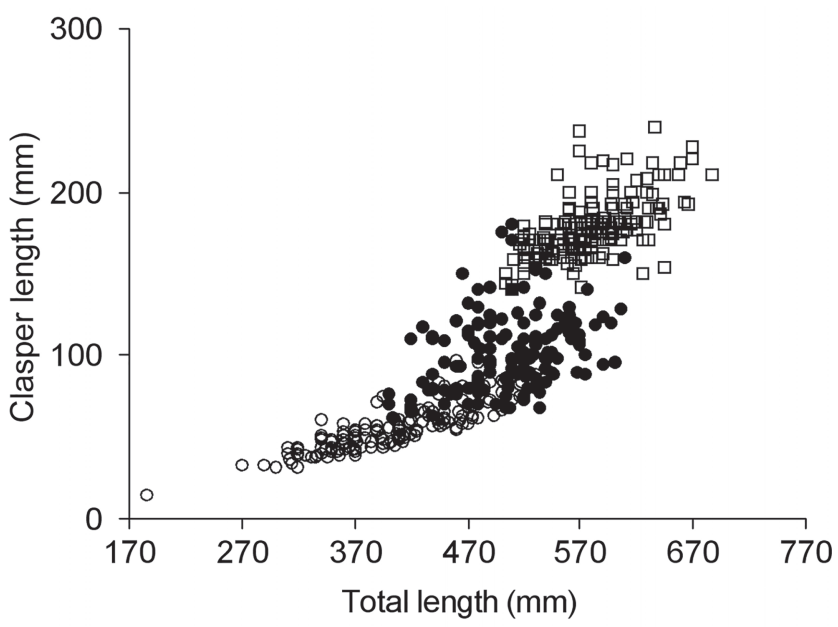

Fig. 3. Total length (TL) and clasper length (CL) relationship of Sympterygia bonapartii from San Matías Gulf (Argentina). Immature (○) $n=166$, maturing $(\bullet) n=$ 145 and mature $(\square) n=193$.

The GSI differed significantly throughout the year $(H=$ $123.25 ;$ d.f. $=11 ; P<0.001$ and $H=145.30 ;$ d.f. $=12 ; P<$ 0.001 for males and females respectively). For males, the GSI exhibited its minimum values from July to November. After that it increased until April, when the maximum value was recorded (Fig. 7). In contrast, the maximum values of GSI for females were recorded from August to December. After that, the GSI decreased until May, when it reached its minimum value (Fig. 7).

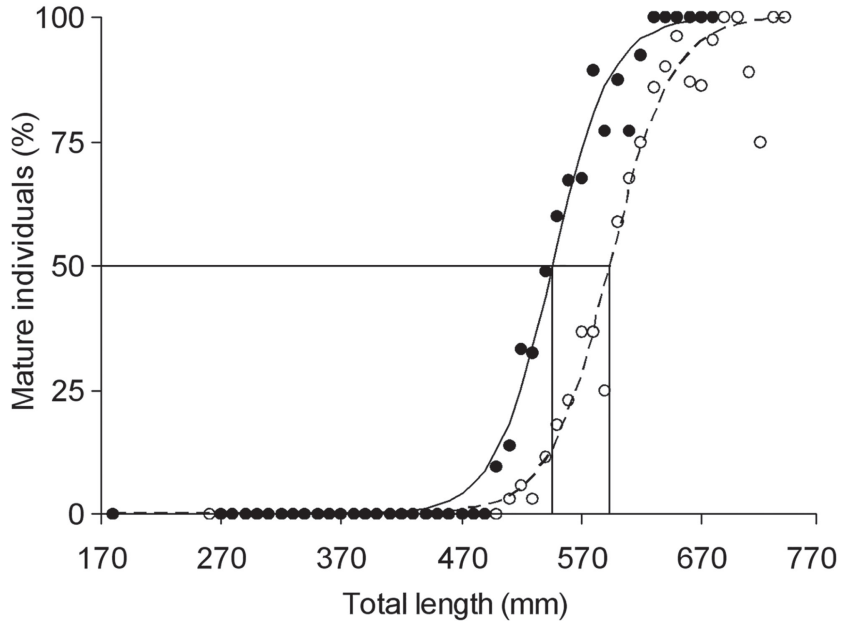

Fig. 4. Size at maturity $\left(\mathrm{TL}_{50 \%}\right)$ of Sympterygia bonapartii from San Matías Gulf (Argentina). Males $(\bullet)$ : $\mathrm{TL}_{50 \%}(-)=$ $545 \mathrm{~mm} ; \mathrm{R}^{2}=0.99 ; n=825$. Females (०): $\mathrm{TL}_{50 \%}(-)=594$ $\mathrm{mm} ; \mathrm{R}^{2}=0.98 ; n=1,268$.

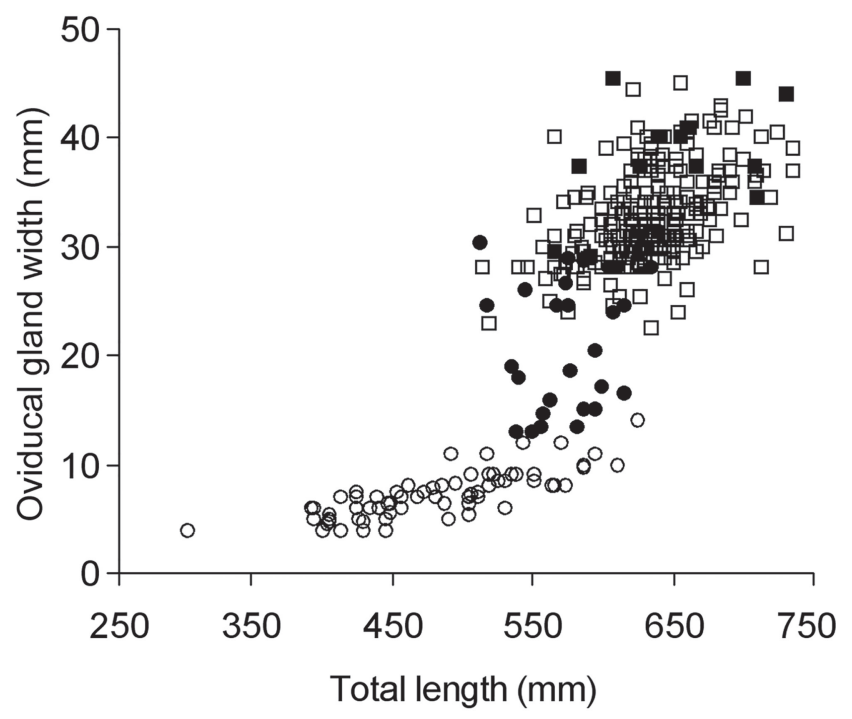

Fig. 5. Total length (TL) and width of the oviducal gland (OGW) relationship of Sympterygia bonapartii from San Matías Gulf (Argentina). Immature (०) $n=69$, maturing $(\bullet) n=30$, mature $(\square) n=263$ and mature females with egg capsules (ロ) $n=11$. 
Tab. 4. Characteristics of the maturity stages of females of Sympterygia bonapartii from San Matías Gulf (Argentina). $T L=$ total length; $O G=$ width of the left oviducal gland; $G W=$ weight of the paired ovaries; $M O D=$ diameter of the largest yolked ovarian oocyte; $N Y O=$ mean number of yolked ovarian oocytes.

\begin{tabular}{lcccc}
\hline Females & Females & Maturing & Mature & $\begin{array}{c}\text { Mature with } \\
\text { egg capsules }\end{array}$ \\
\hline TL range (mm) & $180-625$ & $408-720$ & $514-742$ & $580-730$ \\
OG range (mm) & $4.00-14.00$ & $13.00-31.50$ & $22.50-45.00$ & $34.50-45.50$ \\
mean \pm SD & $7.26 \pm 2.15$ & $22.01 \pm 6.22$ & $32.72 \pm 4.26$ & $40.05 \pm 3.64$ \\
$G W$ range (g) & $0.37-9.27$ & $1.50-16.10$ & $4.95-136.67$ & $42.47-144.42$ \\
mean \pm SD & $3.05 \pm 1.71$ & $7.20 \pm 2.92$ & $37.39 \pm 28.30$ & $79.19 \pm 29.90$ \\
NYO range & - & - & $1-28$ & $5-16$ \\
mean \pm SD & & & $1-26.0 \pm 2.82$ & $5-16.5 \pm 0.71$ \\
$M O D(m m)$ min & - & - & $6.50 \pm 0.70$ & $24.00 \pm 3.54$ \\
$M O D(\mathrm{~mm})$ max & - & - & $38.00 \pm 0.52$ & $38.00 \pm 3.27$ \\
$\mathrm{n}(\%)$ & $327(26 \%)$ & $429(34 \%)$ & $484(38 \%)$ & $28(2 \%)$ \\
Presence & Year round & Year round & Year round & November to \\
NT & & & 1,268 & February \\
\hline
\end{tabular}

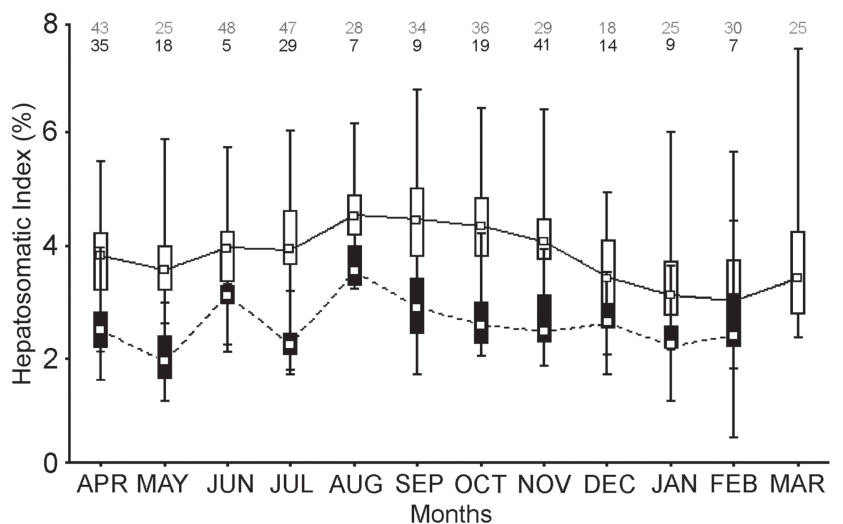

Fig. 6. Monthly variation of the hepatosomatic index (HSI) of Sympterygia bonapartii from San Matías Gulf (Argentina). Mature males ( $\square$ ) and mature females ( $\square$ ). Boxes indicate the percentiles $25-75 \%$; the inner square indicates the median value and bars the range of data distribution. The number of individuals analysed is given in dark grey for females and black for males.

The OGI differed significantly throughout the year $(H=181.42 ;$ d.f. $=12 ; P<0.001)$. It increased from July to November, when its maximum value was recorded, and then decreased until March (Fig. 8). The NYO and MOD also varied significantly throughout the year $(H=79.918$; d.f. $=11 ; P<0.001$ for the NYO and $H=95.73 ;$ d.f. $=11$; $P<0.001$ for the MOD). The NYO increased from July to September-October and after that, decreased until March, when the minimum value was recorded (Fig. 9). The MOD increased from July to December, it remained stable during January and February and it decreased after those months (Fig. 10).

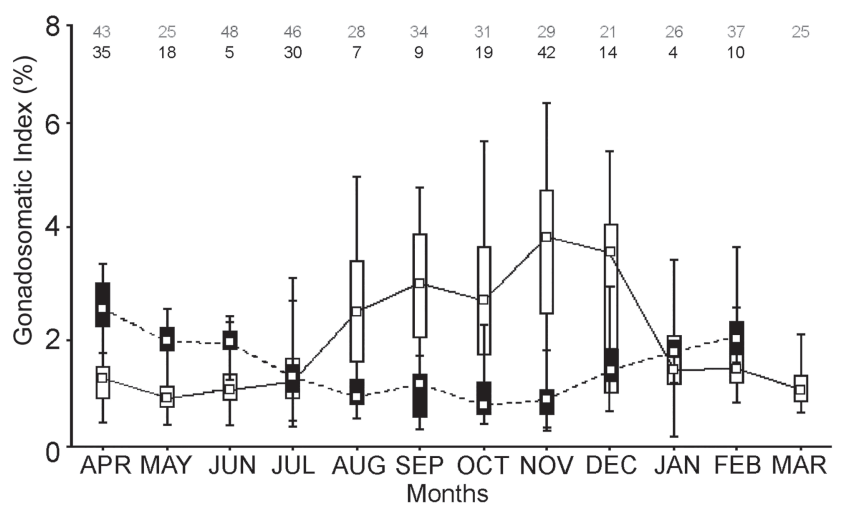

Fig. 7. Monthly variation of the gonadosomatic index (GSI) of Sympterygia bonapartii from San Matías Gulf (Argentina). Mature males (घ) and mature females ( $\square$ ). Boxes indicate the percentiles $25-75 \%$; the inner square indicates the median value and bars the range of data distribution. The number of individuals analysed is given in dark grey for females and black for males.

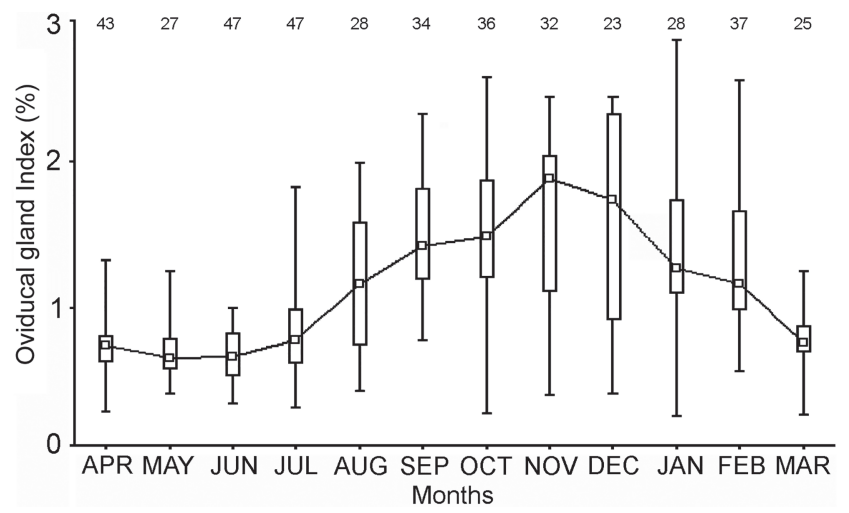

Fig. 8. Monthly variation of oviducal gland index (OGI) of mature females of Sympterygia bonapartii from San Matías Gulf (Argentina). Boxes indicate the percentiles 25-75\%; the inner square indicates the median value and bars the range of data distribution. The number of samples is given in black.

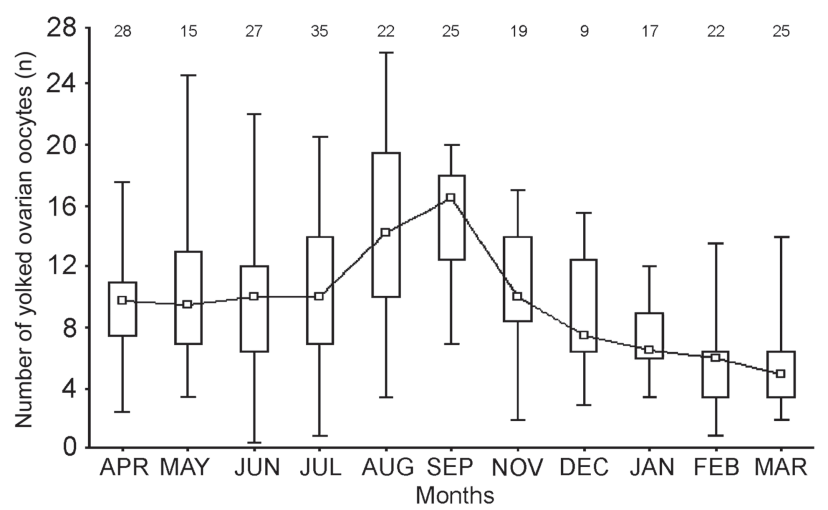

Fig. 9. Monthly variation of the mean number of yolked ovarian oocytes (NYO) of mature females of Sympterygia bonapartii from San Matías Gulf (Argentina). Boxes indicate the percentiles $25-75 \%$; the inner square indicates the median value and bars the range of data distribution. Individuals sampled during September and October were analyzed together. The number of samples is given in black. 


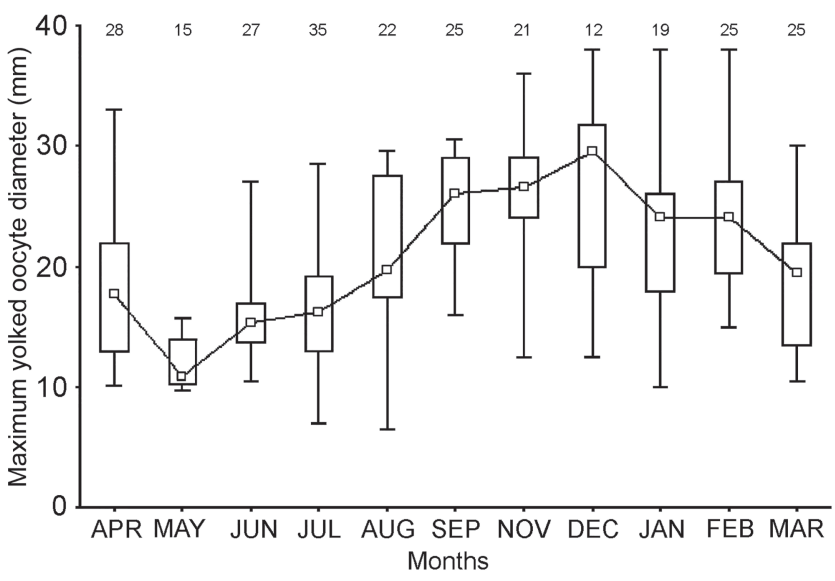

Fig. 10. Monthly variation of the mean diameter of the maximum yolked ovarian oocyte (MOD) of mature females of Sympterygia bonapartii from San Matías Gulf (Argentina). Boxes indicate the percentiles 25-75\%; the inner square indicates the median value and bars the range of data distribution. Individuals sampled during September and October were analyzed together. The number of samples is given in black.

\section{Discussion}

Individuals of $S$. bonapartii exhibited maximum sizes and sizes at maturity smaller than those reported in previous studies (Tab. 5). At least three hypotheses may account for the differences noted. First, the studies differ in the extension of the sampling area, depth range, the sampling procedure and the fishing gear employed. As a result, different sizes of fish may be selected, modifying the size frequency distributions obtained in each work. The differences between the present study and the one of Estalles et al. (2011) are included in this category since in 2011 only the commercial fraction was analysed. The differences may be due to a bias in the size frequency distributions of the skates as a result of the selection of the largest sizes carried out by fishermen on board. The second hypothesis is the presence of geographic variations in the morphological characteristics of the individuals. Increments of skate's size along latitudinal gradients have been reported for many species. They are the consequence of temperature induced changes in growth and metabolism (Frisk, 2010). On the contrary, in SMG, skates exhibited smaller sizes than those recorded in northern locations. This can be related to the unique hydrographic characteristics of the SMG which during spring and summer presents temperatures higher than northern locations.

The last hypothesis is related to fishing. Fish populations under fishing pressure can exhibit changes in their growth rates, size at maturity and reductions in their maximum sizes as a consequence of the selective removal of fish (Kuparinen, Merilan, 2007). During the period 1995-2005, S. bonapartii from SMG experienced a significant reduction in size, probably as a consequence of fishing mortality (Estalles, 2012). A change in size at maturity was already recorded for other skate, the yellownose skate Zearaja chilensis (Guichenot, 1848) as a consequence of decades of heavy exploitation in the South Western Atlantic (Paesch, Oddone, 2008).

Individuals from SMG exhibited sexual dimorphism. Females were larger, heavier and presented heavier livers and wider discs than males of the same TL. Females also matured at larger sizes than males. This pattern of sexual dimorphism in elasmobranch fishes is usually related to an increment in fecundity of the females with larger sizes (Cortés, 2004). However, in skates this trend is not as clear and there are well documented cases of sexes maturing at similar sizes and cases of males maturing at larger sizes than females (Frisk, 2010).

Tab. 5. Comparative size ranges and sizes at maturity reported for Sympterygia bonapartii from San Matías Gulf (Argentina). TL50\%: Size at which 50\% of the individuals reach maturity. AUCFZ: Argentine-Uruguayan Common Fishing Zone. GSM: San Matías Gulf. Estimated using clasper length $(*)$.

\begin{tabular}{|c|c|c|c|c|c|c|}
\hline Sex & $\mathrm{n}$ & TL range $(\mathrm{mm})$ & $\mathrm{TL}_{50 \%}(\mathrm{~mm})$ & Sampling year & Location & Reference \\
\hline M & 92 & $472-768$ & 584 & \multirow{2}{*}{ 2011-2012 } & \multirow{2}{*}{ Southern Brazilian coast $\left(31^{\circ} 29^{\prime}-34^{\circ} 28^{\prime} \mathrm{S}\right)$} & \multirow{2}{*}{ Basallo, Oddone, 2014} \\
\hline $\mathrm{F}$ & 125 & 308-791 & 599 & & & \\
\hline M & 282 & $200-746$ & 651 & \multirow{2}{*}{$1999-2000$} & \multirow{2}{*}{ AUCFZ and Buenos Aires Province $\left(34^{\circ}-42^{\circ} \mathrm{S}\right)$} & \multirow{2}{*}{ Mabragaña et al., 2002} \\
\hline $\mathrm{F}$ & 245 & $227-808$ & 636 & & & \\
\hline M & 123 & $410-780$ & $520-570(*)$ & \multirow{2}{*}{ 1994-1998 } & \multirow{2}{*}{ AUCFZ $\left(34^{\circ} 30^{\prime}-39^{\circ} 30^{\prime} \mathrm{S}\right)$} & \multirow{2}{*}{ Oddone, Velasco, 2004} \\
\hline $\mathrm{F}$ & 436 & $300-790$ & 655 & & & \\
\hline M & 210 & $155-734$ & 580 & \multirow{2}{*}{ 2004-2010 } & \multirow{2}{*}{ Buenos Aires Province, Bahía Blanca estuary $\left(39^{\circ} \mathrm{S}\right)$} & \multirow{2}{*}{ Díaz Andrade, 2010} \\
\hline $\mathrm{F}$ & 387 & $155-780$ & 625 & & & \\
\hline M & 489 & $320-690$ & 560 & \multirow{2}{*}{$2007-2009$} & \multirow{2}{*}{ Río Negro Province, GSM $\left(41^{\circ}-42^{\circ} \mathrm{S}\right)$} & \multirow{2}{*}{ Estalles et al., 2011} \\
\hline $\mathrm{F}$ & 1168 & $340-750$ & 590 & & & \\
\hline M & 812 & $185-687$ & 545 & \multirow{2}{*}{ 2004-2009 } & \multirow{2}{*}{ Río Negro Province, GSM $\left(41^{\circ}-42^{\circ} \mathrm{S}\right)$} & \multirow{2}{*}{ Present study } \\
\hline $\mathrm{F}$ & 1254 & $180-742$ & 594 & & & \\
\hline
\end{tabular}


Several indexes and the presence of females with egg capsules were analysed to assess the reproductive cycle of $S$. bonapartii. In aquaria, the species is able to reproduce throughout the year (Jañez, Sueiro, 2009). However, in this study the analysis indicated that the species presents a seasonal reproductive cycle. The present findings are consistent with those obtained in another study in which wild fishes were analysed (Mabragaña et al., 2002). The differences between individuals held in captivity and those from the wild may be the result of the constant environmental conditions of temperature, photoperiod and salinity of the aquaria (Jañez, Sueiro, 2009).

The mating season of $S$. bonapartii may be set from July to December (winter-spring). During this period, males recorded the minimum values of GSI while females recorded their maximum ones. For males, the minimum values of GSI were used as indicators, since during mating; the weight of the gonads decreases as the sperm moves down the reproductive tract. For females, the maximum values of GSI served as indicators, since as ovulation approaches, the ovaries increase their weight as a result of the storage of yolk in the oocytes (Wilk et al., 1990). For females, HSI showed a seasonal pattern similar to that observed in GSI, NYO and MOD, suggesting a relationship between the liver and reproduction. The liver as well as ovaries are involved in yolk production. Thus, the decrease in HSI values may be due to the constant requirement of vitellogenin, the principal component of yolk, during the egg-laying season (Hamlett, Koob, 1999). In addition, the liver is the organ of energy reserve, and variations in HSI values are associated with the amount of lipids in it (Bone, Roberts, 1969). The irregular pattern observed in HSI values for males make the interpretation difficult. It may be the case that HSI values may be modified as a consequence of a variation in the lipid reserves.

The egg-laying season of $S$. bonapartii may be set from September-October to February (spring-summer). During these months, an increment in the values of the OGI and MOD was recorded together with the presence of females bearing egg capsules. The increment in the values of OGI may be related to the enlargement of the oviducal glands recorded during the mating and the egg-laying season (Galíndez et al., 2010). The increment in MOD values may point out that oocytes were accumulating yolk and were ready to be ovulated when the maximum values were reached. In addition, the NYO diminished after SeptemberOctober indicating that ovulation was undergoing. During March, the GSI, OGI, MOD and NYO in females exhibited low values, suggesting the end of the reproductive season.

Coinciding with the interpretation of the indexes analysed, females with egg capsules were only recorded from November to February. During these months, their proportion among mature females was $<23 \%$. These low records could be the result of a short- distance seasonal migration of $S$. bonapartii to a spawning area. According to previous studies, this species uses shallow areas $<50$ $\mathrm{m}$ near estuaries as egg-laying zones (Mabragaña et al.,
2002). Within the limits of SMG there are no estuaries and there is no evidence that $S$. bonapartii could migrate longdistances outside SMG boundaries to use a spawning area. Moreover, according to mark-recapture studies conducted in other species that reach similar sizes, skates live in confined areas and only make short- distance migrations, probably to reproduce (Templeman, 1984; Walker et al., 1997).

Within the limits of the gulf, a spawning area could possibly be settled in its northern region. This particular environment, which is influenced seasonally by the dynamics of the thermohaline front, has been reported as the spawning area of the chondrichthyan Callorhinchus callorynchus (Linnaeus, 1758) (Di Giácomo, Perier, 1994).

If $S$. bonapartii uses a spawning area in the northern region of the gulf, females bearing egg capsules will be outside the operating range of the local fleet. During spring (October and November) the fleet is restricted to operate in its southern area $\left(41^{\circ} 30^{\prime} \mathrm{S}\right)$ due to the establishment of a seasonal closure to protect the reproduction of $M$. hubbsi, the target species of the bottom trawl fishery. In addition, during summer (January to March) the fleet operates in its southeast region at a depth range averaging from 125 to $135 \mathrm{~m}$, where the maximum yields of $M$. hubbsi are obtained (Romero et al., 2013). Most of the samples of $S$. bonapartii collected in this study came from fishing vessels. The movement of the species beyond the fishing grounds could thus explain the low proportion of females bearing egg capsules recorded.

\section{Acknowledgments}

We thank Tec. Miguel Camarero; Tec. Gimena Mora, Tec. Matías Suarez and Tec. Betiana Rivero for helping us with the samplings. We also acknowledge the local fishprocessing plants "Maritima San José", "Camaronera Patagónica", "Al Pesca" and "Calme Pesquera" for providing us with the biological material and allowing us to sample at their facilities. This work was supported by the Universidad Nacional del Comahue grant: 'Pez gallo, rayas y tiburones del Golfo San Matias: Hacia una explotación pesquera sustentable' 004/M020.

\section{References}

Basallo A, Oddone MC. Reproductive biology of the skates Sympterygia acuta Garman, 1877 and S. bonapartii Müller \& Henle, 1841 (Chondrichthyes: Rajoidei) in south Brazil. Neotrop Ichthyol. 2014; 12(4):771-82.

Bone Q, Roberts BL. The density of elasmobranchs. J Mar Biol Assoc UK. 1969; 49(4):913-37.

Cedrola PV, González AM, Pettovello AD. Bycatch of skates (Elasmobranchii: Arhynchobatidae, Rajidae) in the Patagonian red shrimp fishery. Fish Res. 2005; 71(2):141-50.

Conrath CL. Reproductive biology. In: Musick JA, Bonfil R., editors. Management techniques for elasmobranch fisheries. Rome: Food and Agriculture Organization of the United Nations; 2005. (FAO Fisheries Technical Paper, No. 474). p.103-126. 
Cortés E. Life history patterns, demography, and population dynamics. In: Carrier JC, Musick JA, Heithaus MR, editors. Biology of sharks and their relatives. Boca Raton: CRC Press; 2004. p.449-469.

Di Giácomo EE, Perier MR. Reproductive biology of the cockfish, Callorhynchus callorhynchus (Holocephali: Callorhynchidae), in Patagonian waters (Argentina). Fish Bull. 1994; 92(3):531-39.

Díaz Andrade MC. Morfofisiología de la biología reproductiva de las especies del género Sympterygia que habitan el estuario de Bahía Blanca. [PhD Thesis]. Bahía Blanca: Universidad Nacional del Sur; 2011.

Ebert DA, Compagno LJV. Biodiversity and systematic of skates (Chondrichthyes Rajiformes: Rajoidei). Environ Biol Fish. 2007; 80(2):111-24.

Estalles ML. Características de historia de vida y explotación comercial de la raya Sympterygia bonapartii en el Golfo San Matías. [PhD Thesis]. Buenos Aires: Universidad de Buenos Aires; 2012.

Estalles M, Coller NM, Perier MR, Di Giácomo EE. Skates in the demersal trawl fishery of San Matías Gulf, Patagonia: species composition, relative abundance and maturity stages. Aquat Living Resour. 2011; 24(2):193-99.

Figueiredo JL, Menezes NA. Manual de peixes marinhos do sudeste do Brasil. São Paulo: Museu de Zoologia - Universidade do São Paulo; 1977.

Frisk MG. Life history strategies of batoids. In: Carrier JC, Musick JA, Heithaus MR, editors. Sharks and their relatives II: biodiversity, adaptive physiology and conservation. Boca Raton: CRC Press; 2010. p.283-318.

Galíndez EJ, Díaz-Andrade MC, Avaca MS, Estecondo S. Morphological study of the oviductal gland in the Smallnose fanskate Sympterygia bonapartii (Müller and Henle, 1841) (Chondrichthyes, Rajidae). Braz J Biol. 2010; 70(2):325-33.

Hamlett WC, Koob TJ. Female reproductive system. In: Hamlett WC, editor. Sharks, Skates and Rays: the biology of elasmobranch fishes. Baltimore: The Johns Hopkins University Press; 1999. p.398-443.

Hubbs CL, Ishiyama R. Methods for the taxonomic study and description of skates (Rajidae). Copeia. 1968; 3(1968):483-91.

Jañez JA, Sueiro MC. Oviposition rate of the fanskate Sympterygia bonapartii (Elasmobranchii, Rajidae) (Müller and Henle, 1841) held in captivity. Pan-Am J Aquat Sci. 2009; 4(4):580-82.

Kuparinen A, Merilä J. Detecting and managing fisheries-induced evolution. Trends Ecol Evol. 2007; 22(12):652-59.

Mabragaña E, Lucifora LO, Massa AM. The reproductive ecology and abundance of Sympterygia bonapartii endemic to the south-west Atlantic. J Fish Biol. 2002; 60(4):951-67.

Massa AM, Lucifora LO, Hozbor NM. Condrictios de la región costera bonaerense y uruguaya. In: Sánchez RP, Bezzi SI, editors. Los peces marinos de interés pesquero: caracterización biológica y evaluación del estado de explotación. Mar del Plata: Instituto Nacional de Investigación y Desarrollo Pesquero INIDEP; 2004. (El Mar Argentino y sus recursos pesqueros, vol 4). p.85-99.
Menni, RC, Stehmann MFW. Distribution, environment and biology of batoid fishes off Argentina, Uruguay and Brazil: a review. Rev Mus Argentino Cienc Nat, n.s. 2000; 2(1):69-109.

Oddone MC, Velasco G. Size at maturity of the smallnose fanskate Sympterygia bonapartii (Müller and Henle, 1841) (Pisces, Elasmobranchii, Rajidae) in the SW Atlantic. ICES J Mar Sci. 2004; 61(2):293-96.

Paesch L, Oddone MC. Change in size-at-maturity of the yellownose skate Dipturus chilensis (Guichenot, 1848) (Elasmobranchii: Rajidae) in the SW Atlantic. Neotrop Ichthyol. 2008; 6(2):223-30.

Piola AR, Scasso LM. Circulación en el Golfo San Matías. Geoacta. 1988; 15(1):33-51.

Prager MH, Saila SB, Recksiek CW. FISHPARM: a microcomputer program for parameter estimation of nonlinear models in fishery science. 2nd ed. Norfolk: Old Dominion University Oceanography Technical Report; 1989.

$\mathrm{R}$ Development Core Team. R: a language and environment for statistical computing. Vienna: The R foundation for Statistical Computing. R version 2.11.1. 2010. Available from: https:// www.r-project.org/

Romero MA, Reinaldo MO, Williams G, Narvarte M, Gagliardini DA, González R. Understanding the dynamics of an enclosed trawl demersal fishery in Patagonia (Argentina): a holistic approach combining multiple data sources. Fish Res. 2013; 140(2013):73-82.

Stehmann MFW. Proposal of a maturity stages scale for oviparous and viviparous cartilaginous fishes (Pisces, Chondrichthyes). Arch Fish Mar Res. 2002; 50(1):23-48.

Tamini LL, Chiaramonte GE, Perez JE, Cappozzo HL. Batoids in a costal trawl fishery of Argentina. Fish Res. 2006; 77(3):326-32.

Templeman W. Migrations of the thorny skate, Raja radiata, tagged in the Newfounland area. J Northw Atl Fish Sci. 1984; 5(1):55-63.

Walker P, Howlett G, Millern R. Distribution, movement and stock structure of three ray species in the North Sea and eastern English Channel. ICES J Mar Sci. 1997; 54(5):797-808.

Wilk SJ, Morse WW, Stehlik LL. Annual cycles of gonad-somatic indices as indicators of spawning activity for selected species of finfish collected from the New York Bight. Fish Bull. 1990; 88(4):775-86.

Zar JH. Biostatistical analysis. 2nd ed. Englewood (NJ): Prentice Hall; 1984.
Submitted February 24, 2016 Accepted March 6, 2017 by Michael Mincarone 